\title{
The Effect of Celebrity Endorsement, Electronic Word of Mouth, and Customer Satisfaction to Purchasing Decision
}

\author{
Lenny C. Nawangsari Christina Catur Widayati Aris Edo Crazy \\ Universitas Mercu Buana
}

\begin{abstract}
This study aims to determine the effect of celebrity endorsement, electronic word of mouth and customer satisfaction on consumer purchasing decisions. The population in this study were Miting Lobster visitors in Jakarta, the number of samples used in the questionnaire was 140 respondents. Data collection methods using survey methods, the research instrument is a questionnaire. The data analysis method uses Partial Least Square. This research proves that there is a significant influence between celebrity endorsement on purchasing decisions, there is no influence between the electronic word of mouth with purchasing decisions and there is a significant influence between customer satisfaction with purchasing decisions.
\end{abstract}

Keywords: Miting Lobster, Celebrity Endorsement, Electronic Word Of Mouth, Customer Satisfaction, Purchasing Decision

DOI: $10.7176 / \mathrm{JMCR} / 67-04$

Publication date: April $30^{\text {th }} 2020$

\section{INTRODUCTION}

Every year there is always the latest trend that can attract attention, not to mention culinary. This food world always has its prima donna ready to be hunted and even able to become a promising business area. Seeing the increasing height of the community will culinary tourism, making this a promising business field. "Culinary business opportunities are still very promising. The capital does not have to be large, it involves a lot of labor, and the velocity of money in it can also quickly exceed $100 \%$, "said Amanda Katili, Ambassador for the Indonesia World Food Travel Association. Therefore, the development of the seafood culinary business is quite promising, as were in Indonesia to get seafood raw materials is very easy because the Indonesian State is a maritime country surrounded by oceans, so easily getting these raw materials. Miiting Lobster is one seafood restaurant that is booming.

On the Dyodoran YouTube channel that was aired on June 26, 2018 until November 8, 2018, managed to get a viewer of around 590,037, the number of comments around 829 , the number of likes 5100 , the number of dislike 1100 and the number of subscribers around 30,000. who gave negative comments around 74\% while those who gave positive comments only about $11 \%$ with the high negative comments did not have a significant impact on the sales volume of the Miting lobster restaurant, where during May to October the average number of their transactions was stable around an average of 5704 transactions per month.

According to Kotler and Keller (2016), Word of Mouth is marketing done by people either in the form of oral, written or electronic communication that relates to the good experience of buying or using products and services, is also one form of communication mix which is certainly expected to communicate something to consumers. Entering the current era, technological development is increasing. This is reflected in community activities that are never separated from the internet. With the internet, people can connect with people all over the world. Even though ten years ago the word internet was still taboo in the ears of the people.

Social media is a channel or a means of social interaction online in cyberspace, where social media users can easily communicate and interact, send messages and share and even build networks (networking). Social media that are currently popularly used in Indonesia include Instagram, Facebook, Twitter, and Youtube.

Marketing activities aim to offer a product or service, sometimes using a celebrity or famous figure as an endorser. "Attributes they possess such as expertise, skills, knowledge, experience, intelligence, character, beauty, courage and achievement can be used as important points to attract (potential) consumers" (Pradhan, et al, 2014); (Fleck, et al, 2012).

If we look at the development of social media, the promotion carried out by lobster miting management by displaying the reviews of food bloggers via Youtube is quite effective. And if we search on YouTube, we will find more than 10 YouTube shows that discuss lobster miting. The accuracy of selecting the message source (the endorser) can be based on the attributes attached to the endorser. (Shimp, 2010); (Fleck et al., 2012). The use of celebrity endorser communicators that have characteristics will be able to influence attitudes or positive consumer responses to the product, so consumers will consider it in the buying process and are expected to directly influence behavior through the subconscious (Pradhan et al., 2014); Rifon \& Choi, 2012); (Shafiq, \& Zia-ur-rehman, 2011). e-WOM is proven to play a role in mediating the relationship between e-customer satisfaction and online shop brand image, or in other words, e-WOM is a factor that should be the main concern of the online store manager since it will accelerate the achievement of a positive online shop brand image 
(Riorini and Widayati, 2019). Entrepreneurship orientation is an activity to produce something new, different to think creatively and act innovative in achieving existing opportunity (Astini, R., \& Tafiprios, T. (2017).

Word of Mouth is a communication process of providing recommendations both individually and in groups of a product or service that aims to provide personal information. The relationship between the source of word of mouth and the recipient can also affect the effectiveness of the information being disseminated. Researchers found that the higher the level of similarity and the stronger the relationship between the source and the recipient, the greater the influence of word of mouth will be stronger, and vice versa.

The problems in this study are: (1) Is there an influence of Celebrity Endorsement on consumer purchasing decisions ?; (2) Is there an influence of e-WOM on consumer purchasing decisions ?; (3) Is there an influence of customer satisfaction on consumer purchasing decisions? The purpose of this study is (1) To find out and analyze the effect of celebrity endorsement on consumer purchasing decisions; (2) To find out and analyze the effect of e-WOM on consumer purchasing decisions; (3) To find out and analyze the effect of customer satisfaction on consumer Miting lobster purchase decisions.

\section{LITERATURE REVIEW}

\section{Celebrity Endrosement}

According to A. Shimps (2010), endorsers are advertising supporters or known as ad stars in supporting the advertising of their products. Shimp also divides endorsers into two types, namely: (1) typical-person endorsers are ordinary people who are not known for advertising a product; (2) Celebrity endorser is the use of a famous person (public figure) in supporting an advertisement. Celebrities have an appeal that can be used as an effective strategy when used by advertisers in promoting products and services.

\section{Indicators of Celebrity Endoser}

Source credibility consists of three dimensions that influence the message to be believed and have the power of persuasion by Goldsmith, (2008), namely:

1. Attractiveness. The dimension of attractiveness is the level at which an object is valued through behavior that is sympathetic, has ambition, intelligence, and other personality characteristics. There are five indicators in the dimension of attractiveness, namely: attractive, classy, beautiful, sexy, and elegant.

2. Trustworthiness. The dimension of trust (trustworthiness) is the level where the object is considered an honest source of information. There are five indicators in the dimension of trustworthiness, namely: dependable, honest, reliable, sincere, and trustworthy.

3. Expertise. The dimension of expertise is the level at which an object is assessed through sympathetic behavior, possessing ambition, intelligence, and other personality characteristics. There are five indicators in the dimension of expertise, namely: expert, experienced, knowledgeable, qualified, and skilled.

\section{Electronic Word of Mouth}

Pedersen et al., (2014) argue that Electronic Word of Mouth (eWOM) is the development of Word of Mouth communication that utilizes the power of digital persuasion from consumers about a product. According to Arwidya (2011) in promotional media that influence purchasing decisions, one of them is online word of mouth by saying that word of mouth is interpersonal communication between two more individuals such as reference group members or consumers and salespeople where everyone influences purchases continuously through a communication while word of mouth online is a word of mouth process by using internet or web media. So with activities in eWOM, consumers will get a high level of market transparency, in other words, consumers have a higher active role in the value chain cycle so that they can influence products and prices based on individual preferences (Park and Kirn, 2009).

Understanding Electronic Word of Mouth (eWOM) According to Chatterjee in Jalilvand and Samiei (2012), increased use of the internet and social networking is also an important thing where the current Word of Mouth is not only done individually but can be in any form including the internet called with Electronic Word of Mouth (eWOM). The effectiveness of Electronic Word of Mouth is more effective compared to Word of Mouth communication in the offline world, due to greater accessibility and high reach.

\section{Indicators of Electronic Word of Mouth}

According to Jeong and Jang (2012), e-WOM has the following three Indicators: (1) Concern for Others, namely the desire to help others in making purchasing decisions; (2) Expressing Positive Emotions, which express positive feelings and self-improvement after using the product/service; (3) Helping Company, which is the desire to help the company in return for the company for being satisfied with the product or service

\section{Customer Satisfaction}

According to Lovelock and Wirtz (2011) "Satisfaction is an attitude that is decided based on the experience 
gained. Satisfaction is an assessment of the characteristics or features of a product or service, or the product itself, which provides a level of consumer pleasure related to the fulfillment of consumer consumption needs. Consumer satisfaction can be created through quality, service, and value. The key to achieving customer loyalty is to provide high customer value. According to Kotler \& Armstrong (2016), customer value is the ratio of customers between all profits and all costs that must be incurred to receive the offer given. Total customer costs are a group of costs used in assessing, obtaining and using products or services. Because customer satisfaction is very dependent on customer perceptions and expectations, then as a supplier of products need to know the factors that influence it. A good product is a product that is able to meet the expectations of its customers, so that customers will have a positive experience after buying the product; (2) Subjective Dis-confirmation, customers are satisfied if there are no things or reasons related to product non-conformities that are subjective; (3) Performance Outcomes, customers are satisfied with the overall performance of the products he buys and get optimal benefits in accordance with what he wants (Agus Salim, M., \& Ali, H. (2017).

\section{Indicators of Customers Satisfaction}

According to Maylina (2013), the attributes that makeup customer satisfaction are known as "The Big Eight" which consists of:

1. Value to Price Relationship, which is the relationship between price and product value which is determined by the difference between the value received by the customer for a product produced by a business entity.

2. Product Quality is the quality of all the components that make up the product so that the product has added value or can provide benefits to consumers.

3. Product Features means the physical components of a product that produce benefits.

4. Reliability means a combination of the ability of a product from a reliable business entity, so that a product produced can be by what is promised by the company or by consumer expectations.

5. Warranty is an offer to return the purchase price or make repairs to a damaged product in a condition where a product is damaged.

6. Response to and remedy of problems means the attitude of employees in responding to complaints or assist customers in overcoming problems that occur.

7. Sales Experience means an interpersonal relationship between employees and consumers, especially in terms of communication-related to the purchase.

8. The convenience of Acquisition means the convenience provided by business entities to consumers of the products they produce.

\section{Purchasing Decision}

According to Kotler \& Armstrong (2016) is the stage in the decision-making process of buyers where consumers buy. Decision making is an individual activity that is directly involved in obtaining and using the goods offered. Another definition of a purchasing decision is the buyer's decision about which brand to buy. Consumers can form the intention to buy the most preferred brand. Purchasing decision is a process of decision making about a purchase which includes determining what to buy or not to make a purchase (Kotler and Armstrong, 2016).

\section{Indicators of Purchasing Decisions}

Dimensions and indicators of purchasing decisions according to Tjiptono (2012) explain that the consumer's decision to purchase a product includes six sub-decisions as follows:

1. Product choices Consumers can decide to buy a product or use the money for other purposes. In this case, the company must focus its attention on the people who are interested in buying a product and the alternatives they are considering. For example the need for a product, the diversity of product variants and product quality.

2. Brand choice The buyer must decide which brand to buy. Each brand has its differences. In this case, the company must know how consumers choose a brand. For example brand trust and popularity.

3. Channer's choice The buyer must decide on which supplier to visit. Each buyer has different considerations in terms of determining the supplier can be due to the close location factor, the price is cheap, a complete inventory of goods and others. For example ease of getting products and product availability.

4. Time of purchase. Consumer decisions in choosing the time of purchase can vary, for example, someone buys once a month, three months, six months or once a year.

5. Several purchases Consumers can make decisions about how many products to buy at a time. Purchases made may be more than one. In this case, the company must prepare the number of products according to the different desires of the buyers. For example the need for products. Based on the dimensions and indicators of the purchase decision above, it can be concluded that in measuring purchasing decisions, consumers always consider the choice of products, brands, distributors, time of purchase, and the number of purchases by consumer needs for an item. 


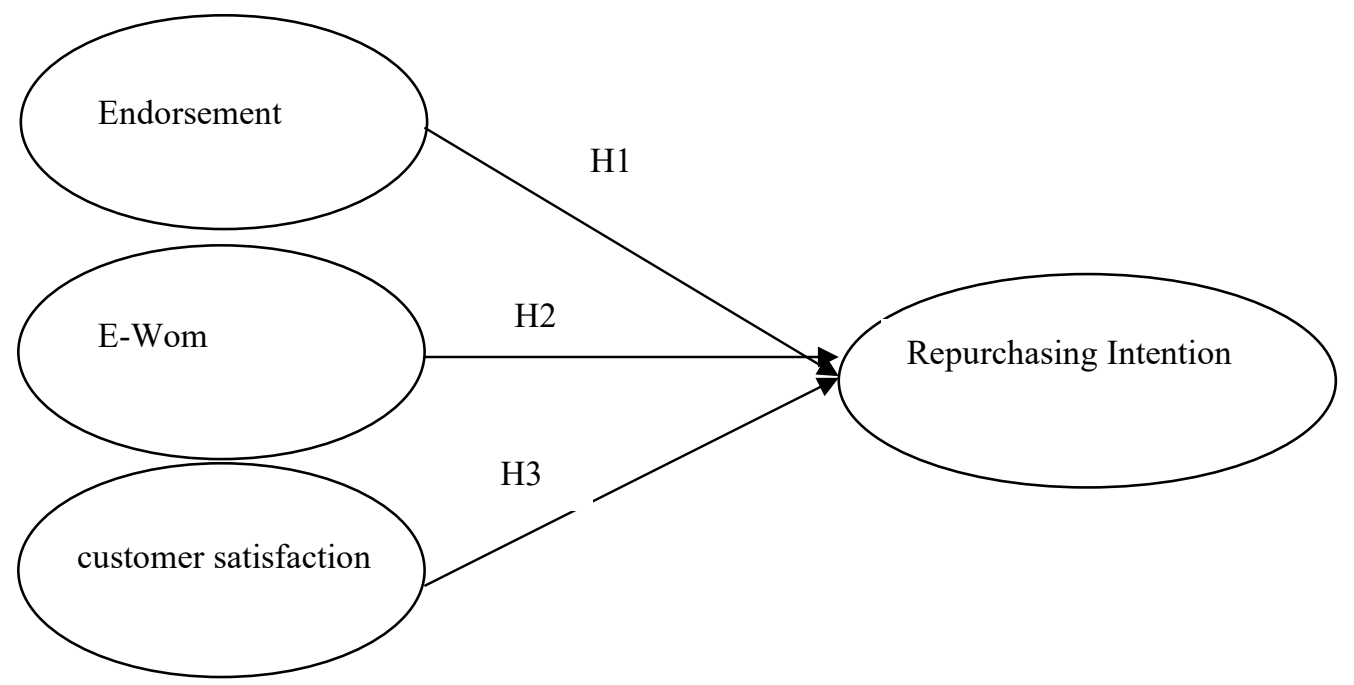

Figure 1. Conceptual Framework

H1: Celebrity Endorsement has a positive and significant influence on purchasing decisions.

$\mathrm{H} 2$ : Electronic Word of Mouth has a positive and significant effect on purchasing decisions.

H3: Customer satisfaction has a positive and significant effect on purchasing decisions

\section{METHOD}

The sampling technique in this study was purposive sampling, where the researchers determined their samples taken because of certain considerations. Samples were taken at random, but determined by the researchers themselves. The technique was chosen because this technique is relatively easy to implement for consumers who are in the Lobster Miting restaurant in the Rawa Sari area of Central Jakarta. The determination of the sample is based on the following criteria, which include: (1) Lobster Miting Consumers; (2) Willing to fill out questionnaires distributed by researchers; (3) Make a purchase at the Lobster Miting in the Rawa Sari area of central Jakarta.

PLS (Partial Least Square) is a component analysis method or variable Based Structural Equation Modeling where the data processing is a Partial Least Square (Smart-PLS) version 3.0 PLS program. PLS is intended for causal-predictive analysis in situations of high complexity and low theoretical support (Ghozali, 2014).

\section{RESULTS AND DISCUSSION}

\section{Partial Least Square (PLS) Model Schematic Analysis Results}

\section{Outer Model}

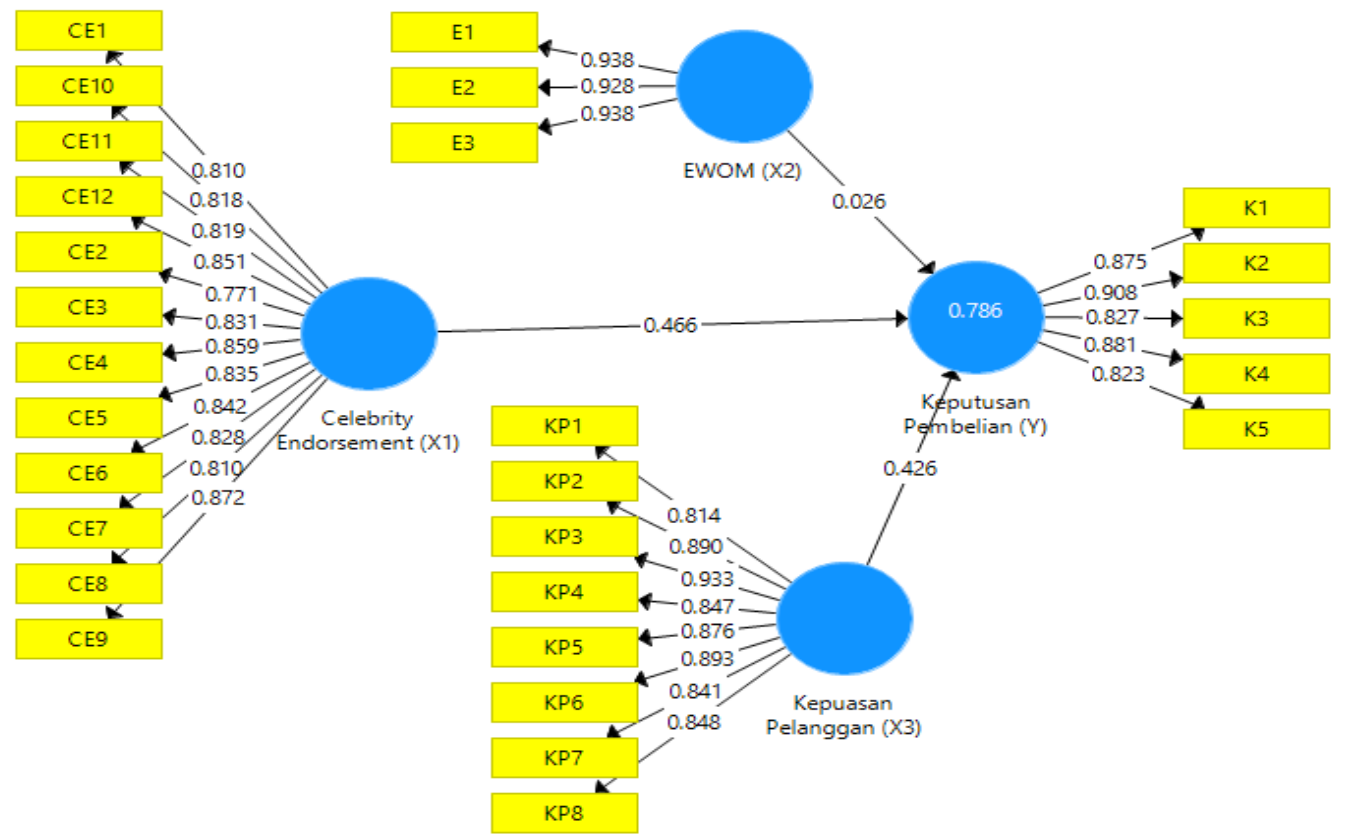




\section{Validity}

\section{Convergent Validity}

\begin{tabular}{cccccccc}
\hline Item & $\begin{array}{c}\text { Celebrity } \\
\text { Endorsement (X1) }\end{array}$ & item & EWOM (X2) & Item & $\begin{array}{c}\text { Customer } \\
\text { Satisfaction (X3) }\end{array}$ & Item & $\begin{array}{c}\text { Purchasing } \\
\text { Decision (Y) }\end{array}$ \\
\hline CE1 & 0,810 & E1 & 0,938 & KP1 & $\mathbf{0 , 8 1 4}$ & K1 & 0,875 \\
CE10 & 0,818 & E2 & $\mathbf{0 , 9 2 8}$ & KP2 & 0,890 & K2 & $\mathbf{0 , 9 0 8}$ \\
CE11 & 0,819 & E3 & 0,938 & KP3 & $\mathbf{0 , 9 3 3}$ & K3 & 0,827 \\
CE12 & 0,851 & & & KP4 & 0,847 & K4 & 0,881 \\
CE2 & $\mathbf{0 , 7 7 1}$ & & & KP5 & 0,876 & K5 & 0,823 \\
CE3 & 0,831 & & & KP6 & 0,893 & & \\
CE4 & 0,859 & & & KP7 & 0,841 & & \\
CE5 & 0,835 & & & KP8 & 0,848 & & \\
CE6 & 0,842 & & & & & & \\
CE7 & 0,828 & & & & & & \\
CE8 & 0,810 & & & & & & \\
CE9 & $\mathbf{0 , 8 7 2}$ & & & & & & \\
\hline
\end{tabular}

An indicator is declared valid if the measurement of the loading factor is above 0.50 so that if there is a loading factor below 0.50 it will be dropped from the model (Ghozali, 2014). Based on the table above it is known that all dimensions of the variable have values above 0.50. This shows that all dimensions of variables are valid and precisely measure these variables. In addition to the Loading Factor value, to analyze the validity of research data one can use the Average Variance Extracted (AVE) value. The following are the results of the validity test using the AVE value.

Table 2. Average Variance Extracted (AVE).

\begin{tabular}{ccc}
\hline Variables & AVE & Description \\
\hline Celebrity Endorsement & 0.687 & Valid \\
EWOM & 0.874 & Valid \\
Customer Satisfaction & 0.755 & Valid \\
Purchasing Desicions & 0.745 & Valid \\
\hline
\end{tabular}

Based on the table above, it is known that all research variables are valid. That is because the AVE value is above the provisions of 0.50 (Ghozali, 2014).

\section{Discriminant Validity}

To test discriminant validity, Ghozali (2015) recommends using reflexive indicators by looking at the value of cross-loading for each variable that must be $>0.50$. or an indicator is declared valid if it has the highest loading factor to the intended construct compared to the loading factor to other constructs. Thus, latent constructs predict indicators in their blocks better than indicators in other blocks. 
Table 3. Discriminant Validity

\begin{tabular}{|c|c|c|c|c|}
\hline Indicators & $\begin{array}{l}\text { Celebrity Endorsement } \\
\text { (X1) }\end{array}$ & $\begin{array}{l}\text { EWOM } \\
(\mathrm{X} 2)\end{array}$ & $\begin{array}{c}\text { Customer Satisfaction } \\
\text { (X3) }\end{array}$ & $\begin{array}{l}\text { Purchasing Decisions } \\
\text { (Y) }\end{array}$ \\
\hline KP8 & 0,523 & 0,382 & 0,588 & 0,513 \\
\hline KP7 & 0,513 & 0,385 & 0,584 & 0,520 \\
\hline KP6 & 0,570 & 0,415 & 0,620 & 0,543 \\
\hline KP5 & 0,531 & 0,377 & 0,608 & 0,486 \\
\hline KP4 & 0,536 & 0,422 & 0,588 & 0,522 \\
\hline KP3 & 0,575 & 0,416 & 0,647 & 0,550 \\
\hline KP2 & 0,552 & 0,452 & 0,618 & 0,492 \\
\hline KP1 & 0,525 & 0,395 & 0,565 & 0,518 \\
\hline K5 & 0,518 & 0,406 & 0,499 & 0,571 \\
\hline K4 & 0,549 & 0,340 & 0,550 & 0,611 \\
\hline $\mathrm{K} 3$ & 0,465 & 0,336 & 0,486 & 0,574 \\
\hline K2 & 0,506 & 0,369 & 0,483 & 0,630 \\
\hline $\mathrm{K} 1$ & 0,545 & 0,406 & 0,554 & 0,607 \\
\hline E3 & 0,437 & 0,651 & 0,445 & 0,411 \\
\hline E2 & 0,390 & 0,644 & 0,400 & 0,361 \\
\hline E1 & 0,456 & 0,651 & 0,459 & 0,430 \\
\hline CE9 & 0,605 & 0,386 & 0,584 & 0,527 \\
\hline CE8 & 0,562 & 0,388 & 0,518 & 0,491 \\
\hline CE7 & 0,575 & 0,414 & 0,513 & 0,548 \\
\hline CE6 & 0,584 & 0,356 & 0,475 & 0,504 \\
\hline CE5 & 0,579 & 0,354 & 0,492 & 0,437 \\
\hline CE4 & 0,596 & 0,400 & 0,538 & 0,492 \\
\hline CE3 & 0,577 & 0,347 & 0,493 & 0,486 \\
\hline CE2 & 0,535 & 0,352 & 0,500 & 0,468 \\
\hline CE12 & 0,590 & 0,406 & 0,543 & 0,534 \\
\hline CE11 & 0,568 & 0,386 & 0,534 & 0,468 \\
\hline CE10 & 0,568 & 0,397 & 0,513 & 0,488 \\
\hline CE1 & 0,562 & 0,377 & 0,488 & 0,508 \\
\hline
\end{tabular}

B. Reliability Test

1. Composite Reliability Test

Table 4. Composite Reliability Test

\begin{tabular}{lcc}
\hline \multicolumn{1}{c}{ Variables } & CR & Description \\
\hline Celebrity Endorsement & 0.963 & Reliable \\
EWOM & 0.954 & Reliable \\
Customer Satisfaction & 0.961 & Reliable \\
Purchasing Decision & 0.936 & Reliable \\
\hline
\end{tabular}

From Table 4 it can be seen that all constructs in the study are stated to be Reliable because the Composite Reliability value for all constructs is above 0.70 (Ghozali, 2015)

\section{Cronbach's Alpha Test}

Table 5. Cronbach's Alpha Test

\begin{tabular}{lcc}
\hline Variables & CA & Description \\
\hline Celebrity Endorsement & 0.959 & Reliable \\
EWOM & 0.928 & Reliable \\
Customer Satisfaction & 0.953 & Reliable \\
Purchasing Decision & 0.914 & Reliable \\
\hline
\end{tabular}

From Table 5 it can be seen that all constructs in the study are stated to be Reliable because the Cronbach's Alpha value for all constructs is above 0.70 . 


\section{Structural Model Test Results (Inner Model)}

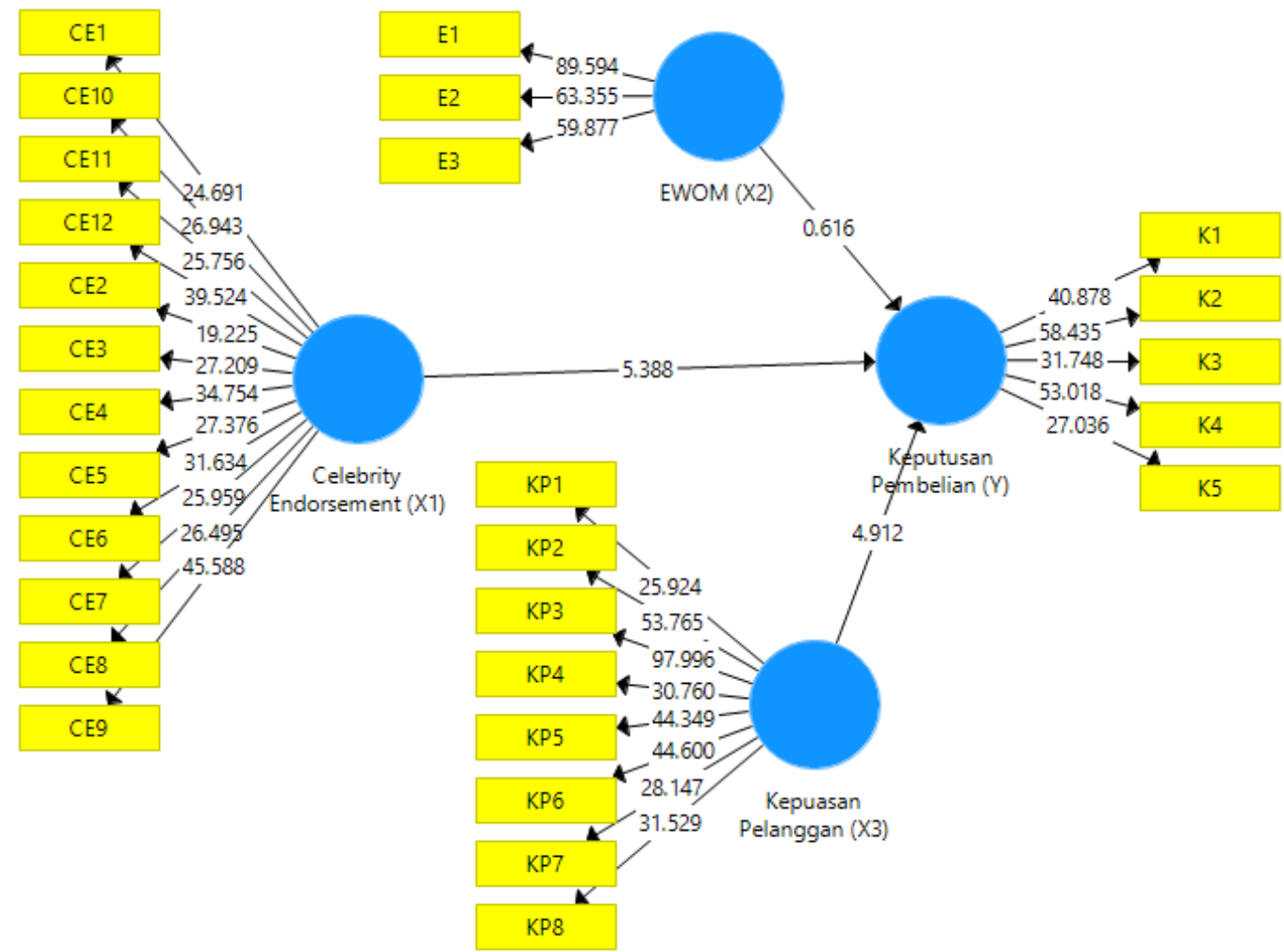

a. Determination Coefficient Test Results (R2)

After the estimated model meets the Outer Model criteria, the next researcher tests the Structural Model (Inner Model), Here is the R-Square (R2) value in the research construct.

Tabel 6. Uji Koefisien Determinasi $\left(\mathrm{R}^{2}\right)$

\begin{tabular}{ll}
\hline & R Square \\
\hline Purchasing Decision $(\mathrm{Y})$ & $\mathbf{0 , 7 8 6}$ \\
\hline
\end{tabular}

This means that the variability of Purchasing Decisions can be explained by the three variables in the model, namely Celebrity Endorsement, EWOM, and Customer Satisfaction of 78.6\%.

\section{b. Test Results for Path Coefficients}

Table 7. Test Results for Path Coefficients

\begin{tabular}{lc}
\hline & Purchasing Decision (Y) \\
\hline Celebrity Endorsement (X1) & 0,323 \\
EWOM (X2) & 0.026 \\
Customer Satisfaction (X3) & 0,295 \\
Purchasing Decision (Y) & \\
\hline
\end{tabular}

The table shows the results of the test of the path coefficient (path coefficients) ranging from 0.026 to 0.323 . It can be concluded that the variable Celebrity Endorsement, Electronic Word of Mouth and customer satisfaction with purchasing decisions have a positive relationship because it has a value close to +1 .

c. T-Statistic Value Test Results

T-Statistic (bootstrapping) is used to see the significant value between constructs. The limit for rejecting and accepting the proposed hypothesis is \pm 1.96 , which if the t-statistic value is in the range of -1.96 and 1.96 then the hypothesis will be rejected or in other words, accept the null hypothesis (H0). 
Table 8. T-Statistic Value Test Results

\begin{tabular}{lcc}
\hline & T Statistics $(|\mathbf{O} / \mathbf{S T D E V}|)$ & Keterangan \\
\cline { 2 - 3 } Celebrity Endorsement $(\mathrm{X} 1)->$ Purchasing Decision $(\mathrm{Y})$ & 5.388 & Significant \\
\hline EWOM (X2) -> Purchasing Decision $(\mathrm{Y})$ & 0,616 & Insignificant \\
\hline Customer Satisfaction $(\mathrm{X} 3)$ - $>$ Purchasing Decision $(\mathrm{Y})$ & 4,912 & Significant \\
\hline d. $\quad$ Model Fit Evaluation & &
\end{tabular}

Goodness of Fit (GoF) GoF Small $=0.1$

Goodness of Fit $(\mathrm{GoF})$ Moderating $=0.25$

Goodness of Fit $(\mathrm{GoF}) \mathrm{Big}=0.38$

Goodness of Fit (GoF) Formula:

$\mathrm{GoF}=\sqrt{ }($ AVE $\mathrm{x}$ Rsquare $)$

$=\sqrt{ }(0.765 \times 0.786)$

$=0.775$

\section{e. Hypothesis Test}

To see the results of the significance of the parameter coefficients can be calculated from the dimensions of variables that have been valid. Researchers want to know there are positive or negative and significant or insignificant effects based on the calculation of $\mathrm{P}$ values that must be below 0.05 and $\mathrm{t}$ statistically greater than 1.96 (Ghozali, 2015). If $\mathrm{t}$ statistic is greater than $\mathrm{t}$ table (1.96) then both constructs are declared significant and vice versa.

Table 9. Hypothesis Test

\begin{tabular}{ccccc}
\hline $\begin{array}{c}\text { Research } \\
\text { Hypothesis }\end{array}$ & Path & $\begin{array}{c}\text { Path } \\
\text { Coeffisien }\end{array}$ & $\begin{array}{c}\text { T Statistics } \\
(|\mathrm{O} / \mathrm{STDEV}|)\end{array}$ & Conclusion \\
\hline H1 & $\mathrm{CE}>\mathrm{K}$ & 0.323 & 5.388 & Positive dan significant \\
$\mathrm{H} 2$ & $\mathrm{E}>\mathrm{K}$ & 0.026 & 0,616 & Positive \& insignificant \\
H3 & $\mathrm{KP}>\mathrm{K}$ & 0.295 & 4,912 & Positive and significant \\
\hline
\end{tabular}

3 (three) Research Hypotheses can be answered as follows:

1. Celebrity Endorsement of Purchasing Decisions

Based on Table 9, it appears that the Celebrity Endorsement Path Coefficient Value for the Purchase Decision variable is positive, that is 0.323 . Then, it can be seen that the $t$ statistic is $5,388 \geq 1.96$ (Ghozali, 2015) so that it can be said to have a positive and significant effect. Thus, the H1 Hypothesis in this study was declared acceptable.

2. Electronic Word of Mouth on Purchasing Decisions

Based on Table 9, it can be seen that the path coefficient value of the Electronic Word of Mouth variable on the Purchase Decision variable is positive, that is 0.026 . Then, it can be seen that the t statistic is $0.616 \leq 1.96$ (Ghozali, 2015) so that it can be said to have a positive and not significant effect. Thus, the H2 Hypothesis in this study was declared rejected

3. Customer Satisfaction of Customer Satisfaction

Based on Table 9, it can be seen that the Path Coefficient Value of the Customer Satisfaction variable to the Purchase Decision variable is positive at 0.295 . Then, a T-statistic of $4.912 \geq 1.96$ is seen (Ghozali, 2015) so that it can be said to have a positive and significant effect. Thus, the H3 Hypothesis in this study was accepted. In conclusion, Customer Satisfaction has a positive and significant impact on Purchasing Decisions.

\section{DISCUSSION}

The results of the Partial Least Square Model (PLS) Schema Analysis of the researcher will describe the discussion in accordance with the 3 Hypotheses that were designed.

1. Celebrity Endorsement Influences Purchasing Decisions. Celebrity Endorsement has a positive and significant influence on Purchasing Decisions. This is similar to research conducted by Michael Y. Angkasa (2017) which states that Celebrity Endorsement has a positive and significant effect on consumer purchasing decisions in terms of purchasing motorcycle products. Similarly, in this study, the figure of Celebrity Endorsement can attract consumers in terms of purchasing decisions Lobster Miting products. In this research, it is known that the Celebrity indicator that most strongly influences purchasing decisions is Experienced where the experience of a Celebrity Endorsement will be able to influence customers to make a purchase, the more experience a Celebrity Endorsement will have, the more influence the customer makes in purchasing decisions compared to the Beautiful indicator because the customer will trust someone more based on their experience or experience compared to their physical appearance. So that Celebrity Endorsements used in introducing their products in accordance with the desired results intended from the benefits of the product will be easier to attract the attention of consumers, so consumers are moved to make purchasing decisions on these products. 
2. Electronic Word of Mouth has no effect on Purchasing Decisions. Electronic Word of Mouth has no positive and significant effect on Purchasing Decisions. In this study, respondents did not care about the comments or reviews given by consumers even though they themselves like to provide information related to lobster miting restaurants online. This is in line with previous research conducted by Tommi and Eristia (2014). This research is not in line with previous studies conducted by Muhamad Juliatrin Chairul Akbar Sunarti (2018) where the results of the study gave rise to that the Electronic Word of Mouth had a high influence on purchasing decisions.

3. Customer Satisfaction has a positive and significant impact on Purchasing Decisions. Customer Satisfaction has a positive and significant influence on purchasing decisions where respondents feel satisfied both in terms of price and service of the research object, the indicator of customer satisfaction variables that most influences on purchasing decisions is the Product Feature indicator where the more complete the facilities provided the more it will encourage customers to make a purchasing decision compared to the Value to price relationship indicator in which in this study customers are more satisfied with the facilities and facilities provided by lobster miting restaurant compared to the price and quality of products offered by lobster miting. This research is in line with research conducted by Muiszudin (2016) which shows that there is a strong and significant correlation between consumer satisfaction with purchasing decisions, so the greater satisfaction felt by consumers will strengthen consumers to make a purchase of a product.

\section{CONCLUSION}

Based on the research results, here are some conclusions in this study: (1) Celebrity Endorsement has a positive and significant effect on Purchasing Decisions; (2) Electronic Word of Mouth has no effect on Purchasing Decisions (3) Customer Satisfaction has a positive and significant effect on Purchasing Decisions.

Based on the conclusion, it is known that Celebrity Endorsement is able to improve purchasing decisions. Therefore, it is recommended to provide interesting content to be presented by Celebrity Endorsement so that the Celebrity Endorsement can attract the attention of customers to make purchases at lobster miting restaurants. As well as choosing Celebrity Endorsements who have extensive experience in the culinary field, for example by bringing in an Indonesian chef master to be reviewed objectively.

Based on the conclusions, it is known that Electronic Word of Mouth is less able to contribute to purchasing decisions seen from the facts in the field where even though negative comments are more than positive comments, it does not have a significant effect on purchases. This is because in this study the influence of Celebrity Endorsement has a related relationship. the most powerful way to influence purchasing decisions.

Based on the results of the conclusion it is known that Customer Satisfaction is able to improve purchasing decisions. Therefore, it is suggested that lobster crab restaurants can improve the quality of products and services of lobster crabs, provide the best prices and improve the quality of products, services, and facilities to be able to continue to increase consumer purchases.

Further research needs to be conducted on the impact of demographics on purchasing decisions because this study shows the majority of buyers in lobster miting restaurants are lower middle class.

\section{REFERENCES}

Aaker, David. (2014). Aaker On Branding. Jakarta: PT Gramedia Pustaka Utama.

Agussalim, M., \& Ali, H. (2017). "Model Kepuasan Pelanggan: Analisis Kualitas Produk Dan Kualitas Layanan Terhadap Citra Merek Pada Giant Citra Raya Jakarta”. Jurnal Manajemen, 21(3), 317-335.

Alma, Buchari. (2014). Manajemen Pemasaran dan Pemasaran Jasa. Bandung: penerbit Alfabeta

Astini, R., \& Tafiprios, T. (2017). The Application of Three Orientation (Market, Technology and Entrepreneurship Orientation) and Global Mindset as Efforts to Increase the Growth and Export Performance: Evidence from Micro, Small and Medium Sized Industries of Teak Furniture in JAVA Island. Journal of Economic \& Management Perspectives, 11(1), 1731-1742.

Bolifar Pakpahan, Eyrck Symon (2017). "Pengaruh Kredibilitas Celebrity Endorsement Terhadap Keputusan Pembelian dan Kepuasan Konsumen You C-1000 Vitamin C di Kota Pekanbaru”. JOMFekon, 4 (1)

Dana Iswara, I Gede Agus (2017) "Peran Brand Image Dalam Memediasi Pengaruh Electronic Word of Mouth Terhadap Purchase Intention (Studi kasus pada produk smarthphone samsung di kota Denpasar)". E-Jurnal Manajemen Unud, 6 (8), 3991-4018

Dasuni, Naynthara Jayarathe. (2018). "Investigation on Impact of eWOM on Social Media Towards The Purchase Intention Consumer in Retail Industry In Srilangka". The International Jurnal of Business \& Management, 6 (12), 30-34

Fungkiya, S., \& Pangestuti, E. (2018). "Pengaruh Electronic Word of Mouth (EWom) terhadap Minat Berkunjung dan Keputusan Berkunjung (Studi pada Wisata Coban Rais BKPH Pujon)". Jurnal Administrasi Bisnis. 54 (1), 189-196 
Kotler, Philip and Gary Amstrong. (2016). Prinsip-prinsip Pemasaran. Edisi 13. Jilid 1. Jakarta:Erlangga

Kotler, Philip and Kevin Lane Keller, (2016). Marketing Management. 15th Edition. New Jersey: Pearson Education,Inc.

Lupiyoadi, Rambat. (2013). Manajemen Pemasaran Jasa Berbasis Kompetensi. Edisi 3. Jakarta: Salemba Empat.

Maria., Dikha, K., Kindangen, P., \& Rumokoy, F.S. (2016). "The Effect of Electronic Word of Mouth on Consumer Buying Decision in Lazada". Jurnal Ekonomi Manajemen Bisnis dan Akuntansi, (EMBA), 4 (1), 974-1096

Juliantrin, Muhamad, (2018). "Pengaruh Electronic Word of Mouth Terhadap Keputusan Pembelian". Jurnal Administrasi dan Bisnis, 60 (3), 45-51

Muizudin (2016)."Pengaruh Kepuasan Konsumen Terhadap Keputusan Pembelian Tiket Pesawat di PT Arwana Internusa Tour Pontianak”. Jurnal Manajemen Motivasi, 12 (1) 626-632

Nugroho, A. (2017). ASEAN Tourism Marketing Communication Attribute: An Exploratory Research at Goaseantv. European Research Studies, 20(3A), 383.

Rachmat Hidayat (2015). "Pengaruh Kepuasan Konsumen Terhadap Keputusan Pembelian Lampu Philips". Ecodomica, 3 (1), 305-310

Rangkuti, Freddy. (2013). Riset Pemasaran. Jakarta: Gramedia Pustaka Utama.

Rima Dwi Anggraeni, \& Edriana Pengestuti (2018). "Pengaruh Endorsement Beauty Vlogger Terhadap Minat Beli” Jurnal Administrasi Bisnis, 60 (1), 155-162

Riorini, S. V., \& Widayati, C. C. (2019). The Role of Electronic Word of Mouth In Improving Brand Image of Online Shop. Jurnal Manajemen, 23(1), 54-68.

Sangadji, E.M., \& Sopiah. (2013). Perilaku Konsumen: Pendekatan Praktis Disertai: Himpunan Jurnal Penelitian. Yogyakarta: Penerbit Andi.

Sari, N., Saputra, M., \& Husein, J. (2017). "Pengaruh Electronic Word of Mouth terhadap Keputusan Pembelian Pada Toko Online Bukalapak. Com”. Jurnal Manajemen Magister. 3 (1), 96-106

Sunyoto, Danang. (2013). Perilaku Konsumen. Yogyakarta: CAPS (Center For Academic Publishing Service).

Thamrin, Abdullah dan Francis Tantri. (2013). Manajemen Pemasaran. cet. II. Jakarta: PT RajaGrafindo Persada.

Tjiptono, F (2014). Pemasaran Jasa: Prinsip, Penerapan, dan Penelitian, C.V Andi Offset, Yogyakarta.

Tjondrokoesumo, Marsellia, (2017). "Celebrity Endorser Terhadap Keputusan Pembelian”. Jurnal Manajemen dan Start Up Bisnis. 3 (2), 287-295

Utami,Wahyu, D., \& Saputri, E. M.,(2016). "Pengaruh Electronic Word of Mouth (E-WOM) terhadap Keputusan Pembelian Pada Konsumen Cafe Roti Gempol dan Kopi Anjis Bandung". e-Proceeding of Management. 3 (2), 92-105

Wijaya, Tommy; Paramitha, Erista Widya,. (2014). "Pengaruh Electronic Word of Mouth Terhadap Keputusan Pembelian Kamera DLSR". Research Methods and Organizational Studies, 12-19 